\title{
Impact of Foreign Direct Investment Inflows on Capital Account of India's Balance of Payments
}

\author{
Mohd Nayyer Rahman \\ University Grants Commission-Senior Research Fellow \\ Department of Commerce, Aligarh Muslim University, India \\ Tel: 91-817-178-8750Ｅ-mail: nayyer49@gmail.com
}

Received: December 30, 2015 Accepted: January 17, 2016

doi:10.5296/ber.v6i1.8965 URL: http://dx.doi.org/10.5296/ber.v6i1.8965

\begin{abstract}
Transfer of capital from one country to another has been unrestricted in the present era of globalisation. The capital transfer may take one form or the other. One of the forms of capital transfer is Foreign Direct Investment Inflows (FDI Inflows) and it is an integral determinant of Capital for developing countries. FDI means the investment of funds by a foreign entity (particularly a Transnational or Multinational Company) by creating new equity base in host or home economy or vice versa. As FDI Inflow is a macroeconomic variable, it is represented in the balance sheet of the country known as Balance of Payments (BOP). The balance of payments of a country is a systematic record of all economic transactions between the residents of the reporting country and residents of foreign countries during a given period of time. To identify the happenings in the international payments, a record of the transactions between countries is necessary. The record of such transactions is made in the balance of payments account. The paper aims to measure the impact of FDI Inflows on Capital Account of India's BOP. The time period for the study is 1991-1992 to 2014-15.
\end{abstract}

Keywords: FDI Inflows, Capital Account, Granger Causality, Vector Auto Regression

\section{Introduction}

When India got Independence in 1947, at that time the Inward FDI in India was by United Kingdom. Just after Independence the task for Indian government was to move on a path of Industrialization. The initial process of Industrialization was supported by domestic as well as international investors. Gradual liberalization was followed by the opening up of the economy by the Indian government in 1991. These changes owing to the liberalization policy has considerable impact on the FDI position of the country both Inward FDI flows and Outward FDI flows. In the aftermath of the 'debt crisis' of the early 1980s, the view that 
'Foreign Direct Investments' (FDI) has a more salutary effect on the Balance of Payments (BOP) of developing countries than debt finance became widespread. This was quite apart from the other benefits of FDI, such as greater productivity, better quality, lower costs, etc. which were taken to be axiomatic. The obvious outcome of such a perception has been a sustained pressure by the multilateral aid agencies and Organisation for Economic Co-operation and Development (OECD) governments on developing countries to actively encourage FDI as an integral part of their BOP management strategy. Several countries consider inviting and attracting FDI Inflows as a directional strategy towards achieving economic development. The primary reason being that FDI comprises of movement of Capital, managerial skills and technology transfer (Egbo, 1998).

During the fiscal year 1990-91, India witnessed a BOP crisis owing to accelerated increase in external debt and a political uncertainty about the leadership. In the view of such development, India's credit rating at the international level deteriorated and it became difficult for the country to fetch foreign financing. This resulted in heavy outflow of foreign reserves and the remittances of NRI's. The only option left for the country was to take funds from IMF under emergency situation. With this background, New Economic Policy (NEP) was adopted in 1991 and with it there was substantial improvement in BOP position of India but yet it has not solved all the problems.

\section{Conceptual Framework}

\subsection{Foreign Direct Investments (FDI)}

FDI refers to the investment of funds by a foreign entity (particularly a Transnational or Multinational Company) by creating new equity base in host or home economy or vice versa. Several definitions of FDI, all giving same notion are found in the existing literature. FDI is investment that is made to acquire a lasting management interest (usually $10 \%$ of voting stock) in an enterprise and operating in a country other than that of the investors (Jhingam, 2008; World Bank, 1996; Sen, 1995). FDI is cross border investments in which a resident in one economy acquires a lasting interest in an enterprise in another economy. FDI is identified when the foreign investor acquires at least $10 \%$ or more of the ordinary shares or voting rights of an enterprise abroad. To qualify as an FDI, the investment must be made by one investor or by a "related group" of investors (IMF, 2003). FDI reflects the objective of obtaining a lasting interest by a resident entity in one economy other than that of the investor. The lasting interest implies the existence of a long term relationship between the direct investor and the enterprise and a significant degree of influence on the management of the enterprise (OECD, 2008). FDI includes both Inflows and Outflows, the former referring to flow of equity funds into the host country and the latter referring to flow from the home country. FDI Inflows includes not only merger and acquisitions and new investment but also reinvested earnings and loans and similar capital transfer between parent companies and their affiliates.

\subsection{Balance of Payments (BOP)}

According to Kindleberger (1985), "The balance of payments of a country is a systematic 
record of all economic transactions between the residents of the reporting country and residents of foreign countries during a given period of time". For the purpose of identifying the happenings in the international payments governments keep record of the financial matters between countries. The record of such transactions is made in the balance of payments account (Lipsey \& Chrystal, 2007). BOP is further divided into two major parts, namely:

The current account (CA), which includes the recording of all transactions related to trade in goods and services and also includes transfers. On the other hand, capital account records transactions related to financial assets, foreign investments, short term and long term lending. In short, capital account shows changes in the country's foreign assets and liabilities.

The capital account (KA), that consists of its transactions in financial assets in the form of short term and long term lending and borrowings and private and official investments. In other words, the capital account shows international flow of loans and investments, and represents a change in the country's foreign assets and liabilities. Long term capital transactions relate to international capital movements with maturity of one year or more and include direct investments like building of a foreign plant, portfolio investment like the purchase of foreign bonds and stocks, and international loans. On the other hand, short term international capital transactions are for a period ranging between three months and less than one year (Jhingam, 2008).

\section{Review of Literature}

The review of existing literature shows a mixed response towards the impact of FDI on components of BOP, though very few studies are available on the causal relationship. In addition to it, FDI Inflows has not been taken up specifically to measure its impact on BOP. Empirical evidence with respect to causality between FDI and Trade has shown contradictory results ranging from uni-directional causality to bi-directional causality and even no causality between the two variables (Pramadhani, Rakesh \& Driffield, 2007). The bivariate causality tests carried out by Thornton (1996) and Abdulnasser and Manuchehr (2000) shows a uni-directional Granger Causality from exports to economic growth. In this context, focusing only on trade may not be appropriate (Goldberg \& Klein, 1999). This refers to the need of measuring the impact of FDI Inflows on BOP. The effects of Foreign Direct Investment on home and host economies have been the subject of much writing (Dunning, 1981, 1993; Enderwick, 1985, Hufbauer \& Adler, 1968; Ietto-Gillies, 1992; Reddaway, 1967, 1968; UNCTAD, 1992, 1997). The empirical results indicate that FDI has a negative effect on current account and a positive effect on capital account. FDI and its impact have drawn attention of scholars but lately. Chakraborty and Basu (2002) suggest that GDP in India is not Granger caused by FDI and the causality runs more from GDP to FDI. Still it does not build a relationship between FDI Inflows and BOP. Fry, Claessens, Burridge and Blanchet (1995) suggested that the more liberal is a country's foreign exchange system the more likely is FDI to be independent showing a null impact on BOP. Baye and Jansen (1995) observed the patterns of macroeconomic variables and concluded that FDI will have a positive impact on private investment and growth but the caution point is that it can also have an adverse effect 
on BOP. This study focused on Thailand. Sahoo and Mathiyazhagan (2002) suggested that there is a long-run relationship between Gross Domestic Product (GDP), FDI, and Export (EX) and also argued that FDI does not matter in the growth of the economy, but export contributes to the growth in India. Out of the several studies focussing on the case of developing countries, majority of them concludes that FDI has significant positive impact on economic growth. The economic impact of FDI on the level of economic activity has been widely investigated in recent years across different countries. Results from studies suggest that FDI Inflows can crowd-in or crowd-out domestic investment depending on the specific elements of the economy. However, overall FDI has a positive impact on economic growth. The key factors in determining the magnitude of the impact included availability of resources, stock of human capital etc. (Hossain, 2007). In recent years, however, the lustre has worn somewhat thin on this prescription, principally due to emerging empirical evidence which suggest that FDI may have a more positive impact on the BOP of the originating country than on that of the recipient country (Sen, 1995). The empirical observation that profits on FDI often climb quite steeply after an initial period of unprofitability suggests that FDI should not generally be viewed as a means of financing Balance of Payments needs over the medium term (World Bank, 1993). There is of course an enormous body of literature on the microeconomic dimensions of FDI, particularly on the behaviour of trans or multinational corporations, but this is of limited relevance to the BOP implications.

Thus, capital inflows which comprises of FDI Inflow are a good source of improving the BOP position (Nag \& Mukherjee, 2012). Balance of Payments is a matter of concern for emerging economies given the history of their development (Kulkarni \& Kamaiah, 2015). Ranjan and Nachane (2004) developed a model of India's BOP divided into five equations including (a) current account of BOP (b) capital account of BOP and external debt (c) output and price determination (d) money supply and bank credit (e) fiscal sector including market borrowings. He reached to a conclusion that the exchange rate adjustment would not lead to substantial improvements in macroeconomic conditions. Both FDI and FPI, apart from market efficiency contribution help to finance the deficit of BOP and preserve the foreign currency reserves (Ahmad, Yang \& Draz, 2015).

It was also highlighted that FDI normally has a significantly higher Capital Account entry associated with it than the corresponding Current Account entry (Sen, 1995). Catao and Milesi-Ferretti (2013) has seen crisis in the light of debt rescheduling by the emerging economies and on the basis of IMF assistance program related to debt. This directly is related to Capital Account of BOP. Against the background of the liquidity crisis of BOP before 1991 liberalisation, management of the Capital Account has assumed critical importance in the overall framework of macroeconomic decision making in India (Ranjan \& Nachane, 2004). The Capital Account of India has shown a rising trend since 1990's as highlighted by Kaur, Yadav and Gautam (2012). Achieving macroeconomic stability through BOP is the pre-condition for optimising external sector policies affecting trade, exchange rate and the management of reserves. The policies to be adopted with respect to Capital Account of BOP must include the understanding on the issues such as characteristics of capital flows (FDI Inflows), cost consideration (including transfer pricing) and modalities of monetary and fiscal 
policies in the interests of macroeconomic stability (Ranjan \& Nachane, 2004). With the changing composition and dimensions of capital flows, the focus is rapidly shifting towards individual constituents in the Capital Account. As an example to cite, in recent years, the Capital Account has been dominated by flows such as FDI, PI (including GDR issues), commercial borrowings and non- resident deposits. Though, it is a fact that traditionally for India the major item in Capital Account was external aid. The model of Capital Account of BOP developed by Ranjan and Nanchane (2004) focused on two interactive channels through which the Capital Account of BOP impacts the rest of the economy. However, it is assumed that Capital Account would supplement domestic savings to raise gross investment in the economy which would further affect output growth. When and if capital inflows (FDI particularly) are large such inflows are absorbed by RBI which leads to a rise in the foreign exchange reserves and subsequently to money supply accelerations. Ultimately, it was concluded that in context of India, Capital Account is adversely affected as a result of slowdown in world income which also resulted in less inflows of foreign savings into India. Thus, when the world GDP declines, though real growth rate of India is not affected the impact of the same can be felt on other parameters like capital inflows (FDI Inflows), reserves, money supply, inflation and revenue collection of the government of India (Ranjan $\&$ Nachane, 2004).

\section{Econometric Models and Estimation Methods}

In order to decide the causality or impact between the relevant variables Toda and Yamamoto (1995) non causality approach would be followed. This would be along with the application of the direct approach without the Difference Stationary Process (DSP) and would be using the data in levels. However, it does not mean that order of integration of the series would not be checked. The estimation approach used in this study has been captured by Lutkepohle (2007). Variables used in the study are described in Appendix 1. A simple X Granger cause Y if $\mathrm{Y}$ can be better predicted using the histories of both $\mathrm{X}$ and $\mathrm{Y}$ than it can by using the history of Y alone.

With respect to the study, the combination to be studied is FDI Inflows (FDII) and Capital Account Balance (KAB). The absence/presence of Granger causality will be tested using the following set of equation:

Set 1: FDII and KAB

$$
\begin{gathered}
F D I_{t}=a_{0}+a_{1} F D I I_{t-1}+\ldots+a_{p} F D I I_{t-p}+b_{1} K A B_{t-1}+. .+b_{p} K A B_{t-p}+\mu_{t} \\
K A B_{t}=c_{0}+c_{1} K A B_{t-1}+\ldots+c_{p} K A B_{t-p}+d_{1} F D I_{t-1}+. .+d_{p} F D I I_{t-p}+v_{t}
\end{gathered}
$$

The hypotheses for equation 1.1 are as follows:

$\mathrm{H}_{0}$ : Capital Account Balance does not Granger cause FDI Inflows

$\mathrm{H}_{\mathrm{A}}$ : Capital Account Balance Granger cause FDI Inflows

Maintained/ Mathematical hypotheses for the same are as follows: 
$\mathrm{H}_{0}: \mathrm{b}_{1}=\mathrm{b}_{2}=\ldots=\mathrm{b}_{\mathrm{p}}=0$

$\mathrm{H}_{\mathrm{A}}: \mathrm{b}_{1} \neq \mathrm{b}_{2} \neq \ldots \neq \mathrm{b}_{\mathrm{p}} \neq 0$

The hypotheses for equation 1.2 are as follows:

$\mathrm{H}_{0}$ : FDI Inflows does not Granger cause Capital Account Balance

$\mathrm{H}_{\mathrm{A}}$ : FDI Inflows Granger cause Capital Account Balance

Maintained/ Mathematical hypotheses for the same are as follows:

$\mathrm{H}_{0}: \mathrm{d}_{1}=\mathrm{d}_{2}=\ldots=\mathrm{d}_{\mathrm{p}}=0$

$\mathrm{H}_{\mathrm{A}}: \mathrm{d}_{1} \neq \mathrm{d}_{2} \neq \ldots \neq \mathrm{d}_{\mathrm{p}} \neq 0$

The first step in the procedure is to find out the order of integration of the series FDII and KAB by using both Augmented Dicky Fuller unit root test (Dicky \& Fuller, 1981) and Kwiatowski Phillips Schmidt Shin unit root test (Kwiatowski, Phillips, Schmidt \& Shin, 1992). The various models and hypothesis for ADF test are as follows:

Model A: Check for Stationarity (Neither intercept nor trend)

$$
\Delta y_{t}=\gamma y_{t-1}+\sum P_{i} \Delta y_{t-i}+\epsilon_{t}
$$

Model B: Check for Level Stationarity (Only Intercept in the equation)

$$
\Delta y_{t}=\mu+\gamma y_{t-1}+\sum P_{i} \Delta y_{t-i}+\epsilon_{t}
$$

Model C: Check for Trend Stationarity (Intercept and Trend in the equation)

$$
\Delta y_{t}=\mu+\beta t+\gamma y_{t-1}+\sum P_{i} \Delta y_{t-i}+\epsilon_{t}
$$

Where in all cases $\mathrm{H}_{0}: \gamma=0$ of a unit root time series

$\mathrm{H}_{\mathrm{A}}: \gamma<0$ of a stationary time series

As there are differences in asymptotic distribution of the different unit roots, for a cross check, KPSS test would also be used. Remember, that while the null hypothesis of ADF is non stationarity, the null hypothesis of KPSS is stationarity. In KPSS only two models are available:

Model A: Check for Level Stationarity (Only Intercept)

$y_{t}=a_{0}+\varepsilon_{t}$

Model B: Check for Trend Stationarity (Intercept and Trend in the equation)

$$
y_{t}=a_{0}+\beta t+e_{i}
$$


Where in all cases $\mathrm{H}_{0}: \sigma_{\mu}^{2}=0$ of a stationary time series

$\mathrm{H}_{\mathrm{A}}: \sigma_{\mu}^{2} \neq 0$ of a unit root/non stationary series

Thus, combining the results of ADF and KPSS is the ideal method in checking for stationarity and deciding the order of integration (Kocenda \& Cerny, 2014). Once the integrated order is confirmed, Vector Auto Regression (VAR) model would be developed for the two sets in levels of the data. VAR models in time series analysis may be traced to Sims (1980). It is the most appropriate approach in case of two variables interacting with each other when there is no ex ante information that which of them is exogenous. The following are the equations for unrestricted VAR model:

Set 2: FDII and KAB

$$
\begin{gathered}
F D I_{1 t}=b_{1}+\alpha_{12} K A B_{2 t}+\sum_{i=1}^{p}\left(\gamma_{11}^{(i)} F D I I_{1 t-i}+\gamma_{12}^{(i)} K A B_{2 t-i}\right)+\mu_{1 t} \\
K A B_{2 t}=b_{2}+\alpha_{21} F D I I_{1 t}+\sum_{i=1}^{p}\left(\gamma_{21}^{(i)} F D I_{1 t-i}+\gamma_{22}^{(i)} K A B_{2 t-i}\right)+\mu_{2 t}
\end{gathered}
$$

For estimating the VAR model, determination of number of lags $\mathrm{p}$ would be done on minimizing the Akaike Information Criteria (AIC), Hannan-Quinn Information Criteria (HQIC) and Schwarz Bayes Information Criteria (SBIC). Additionally, there should be no serial correlation in the model and this would be judged through residual statistics (LM serial correlation test). Inverse roots of AR Characteristic polynomial would additionally determine whether the VAR model is stable or not. Cross checking of the results would also be performed with the help of Johansen's methodology of cointegration. If the two series are found to be cointegrated while Granger causality suggest otherwise, the results of causality would not be considered reliable. However, if the two series are not cointegrated, the Granger causality results cannot be cross checked and the results would be considered reliable.

\section{The Data}

The secondary data is collected from Department of Industrial Promotion and Policy (DIPP), Government of India; UNCTAD Database and Reserve Bank of India database. FDI Inflows data has been taken from DIPP and UNCTAD while the Balance of Payments data from RBI database. The FDI data previous to financial year 2000-01 was not available on DIPP database. On the other hand, though the data from 1991 was available on UNCTAD, it was on annual basis while the financial/fiscal year for India's macroeconomic variables is April 1 of one year to $31^{\text {st }}$ March of next year. Thus, the UNCTAD data was transformed into the financial/fiscal year data. For this it was assumed that FDI Inflows were distributed evenly in 


\section{Macrothink}

Business and Economic Research

ISSN 2162-4860 2016, Vol. 6, No. 1

an annual year. Because the data is annual, it is to be noted there is no such problem of seasonality. Thus, the annual data from 1991 to 2000 was transformed into the data from 1991-1992 to 1999-2000. The equation used for transforming the data is as follows:

$f d i i_{t}=f d i i_{t+1} \div 12 \times 3+f d i i_{t-1} \div 12 \times 9$

Where:

$\mathrm{t}=$ period, e.g. 1991-1992

$\mathrm{t}+1=$ latter year, e.g. 1992 for the above period

t-1 = previous year, e.g. 1991 for the above period

The matrix of the data for three variables is presented in Appendix 2.

\section{Impact of FDI Inflows (FDII) on Capital Account Balance (KAB) of India's BOP}

The trend in FDII and KAB needs to be discussed. During the period 1991-92 to 2014-15, the FDII and CAB data has shown myriad trends. While the FDI Inflows has been consistently increasing with fluctuation and downfall in few selected years, the rate of increase appears to be more after 2006-07. Figure 1 highlights the trends in the levels of the data of FDI Inflows and KAB. As it is clear from the graph, KAB has shown substantial fluctuation in 2008-09 and 2012-13. These changes may be traced to policy changes from time to time and particularly year 2008-09 may be linked to world economic crisis due to which there was a setback to the flow of cross border capital. The descriptive of the two series shows the mean value of US\$ 16010.26 million for FDII and US\$ 30784.38 million for KAB with a maximum value of US\$ 46556 and US\$ 106585 million, respectively. The minimum value of FDII and KAB in the sample period is US\$ 119.25 million and US\$ 3876 million. The prob. value of Jarque-Bera shows that FDII series is normally distributed (0.1735) and KAB series is also normally distributed (0.0855). The other descriptive can be looked at in Appendix 4.

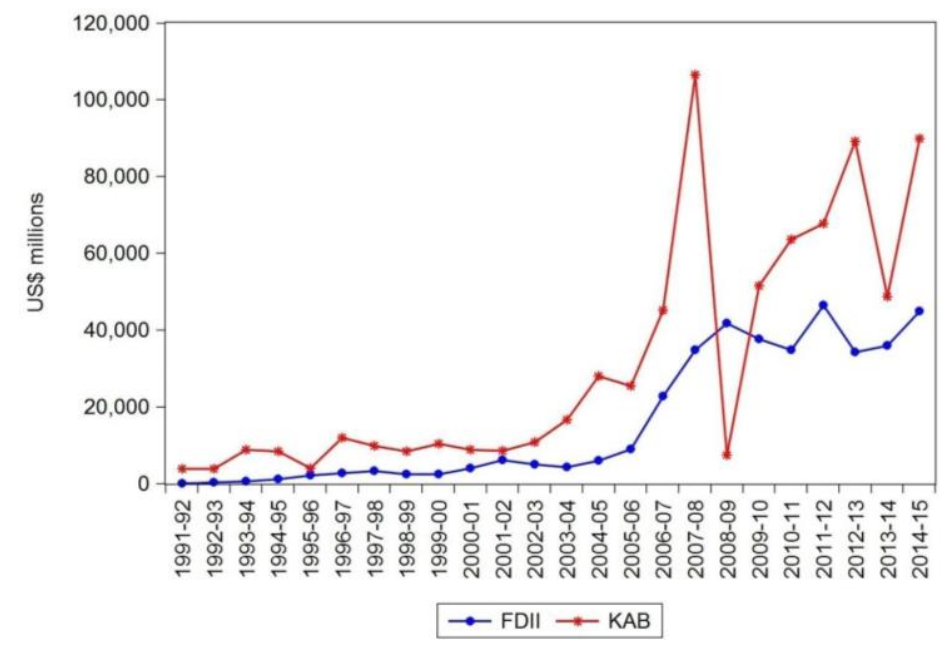

Figure 1. FDII and KAB

Source: Prepared by the researcher 
Both the time series FDII and KAB, have been checked with ADF and KPSS unit root tests in order to find the integrated order individually and after that the maximum integration of both the series. First, the FDII series is checked for integration order. For the same, first the type of unit root model needs to be selected and conformed. The best way is to check whether there is trend or not in the series. If there is trend which comes out to be significant, than the unit root model used would be model C (both intercept and trend).

Table 1. Unit Root Test for FDII (ADF Test)

\begin{tabular}{|l|l|l|l|l|}
\hline Data & Critical Value & Level of Sig. & Absolute t-statistic & Prob. \\
\hline \multirow{4}{*}{ Level } & 4.3943 & $1 \%$ & & \\
& 3.6122 & $5 \%$ & \multirow{3}{*}{1.8848} & \multirow{3}{*}{0.6310} \\
\cline { 2 - 3 } & 3.2431 & $10 \%$ & & \\
\hline \multirow{2}{*}{$1^{\text {st }}$ Order Difference } & 4.4163 & $1 \%$ & & \multirow{3}{*}{4.28} \\
\cline { 2 - 3 } & $\mathbf{3 . 6 2 2 0}$ & $5 \%$ & $\mathbf{0 . 0 1 3 3}$ \\
\cline { 2 - 3 } & $\mathbf{3 . 2 4 8 6}$ & $10 \%$ & & \\
\hline
\end{tabular}

*bold values indicate stationarity

Source: Computed by researcher using eviews 9

Table 2. Unit Root Test for FDII (KPSS Test)

\begin{tabular}{|l|l|l|l|}
\hline Data & Asymptotic Critical Value & Level of Sig. & LM Statistic \\
\hline \multirow{3}{*}{ Level } & $\mathbf{0 . 2 1 6 0}$ & $1 \%$ & \\
\cline { 2 - 3 } & $\mathbf{0 . 1 4 6 0}$ & $5 \%$ & \multirow{3}{*}{0.1324} \\
\cline { 2 - 3 } & 0.1190 & $10 \%$ & \\
\hline \multirow{2}{*}{$1^{\text {st }}$ Order Difference } & $\mathbf{0 . 2 1 6 0}$ & $1 \%$ & \multirow{3}{*}{0.0688} \\
\cline { 2 - 3 } & $\mathbf{0 . 1 4 6 0}$ & $5 \%$ & \\
\cline { 2 - 3 } & $\mathbf{0 . 1 1 9 0}$ & $10 \%$ & \\
\hline
\end{tabular}

*bold values indicate stationarity

Source: Computed by researcher using eviews9

The series indicates when FDII is checked for unit root with ADF test (deterministic trend model) the output of trend shows the prob. value to be 0.0452 which is less than $5 \%$. Thus, the null hypothesis of "no significant trend" is rejected and alternative hypothesis of trend is accepted. Thus, the dynamics of the series can be captured with a unit root model including intercept as well as trend. Table 1 and Table 2 gives the unit root test results for ADF and KPSS. It is clear from Table 1 that FDII series is non-stationary at all levels and prob. value is also more than $5 \%$ when the data is level. Thus, there is a need for difference stationary process (DSP). The first order difference stationarity check results shows that FDII I(1) is stationary as the prob. is less than 5\% (0.0133) and absolute t-statistic is more than critical values at $5 \%$ and $10 \%$.

The same series is checked for unit root with the help of KPSS where null hypothesis is of 
stationarity. The results are shown in Table 2. The level data shows that series is non stationary at only $10 \%$ level but stationary at $1 \%$ level and $5 \%$ level. The null hypothesis of stationarity is rejected when the LM statistic is more than the appropriate critical value. The two results of ADF and KPSS if combined seems contradictory and thus requires reconciliation. A close look to the KPSS result show that at 5\% level the values are close enough to decide that $5 \%$ seems to be a typical unit root (meaning just in the middle of stationary series and non- stationary series). In practice, it is common to have a series as non stationary by ADF and stationary by KPSS though the opposite is not common. The decision here taken is to further go for differencing and then again checking unit root by KPSS. Thus, at first order differencing unit root testing, the series FDII is stationary at all levels because at all levels the LM statistic is less than the appropriate critical value. Combining the results of ADF and KPSS, it is concluded that FDII is of order 1 by ADF and order 0 or 1 (much stronger) by KPSS. Thus, as reconciliation, FDII is integrated of order 1. Moving on to check the series KAB for finding the order of integration. The series is checked for both ADF and KPSS. Table 3 and Table 4 represent the results of the test.

Table 3. Unit Root Test for KAB (ADF Test)

\begin{tabular}{|l|l|l|l|l|}
\hline Data & Critical Value & Level of Sig. & Absolute t-statistic & Prob. \\
\hline \multirow{3}{*}{ Level } & $\mathbf{4 . 3 9 4 3}$ & $1 \%$ & & \\
\cline { 2 - 3 } & $\mathbf{3 . 6 1 2 2}$ & $5 \%$ & \multirow{2}{*}{5.2092} & $\mathbf{0 . 0 0 1 7}$ \\
\cline { 2 - 3 } & $\mathbf{3 . 2 4 3 1}$ & $10 \%$ & & \\
\hline
\end{tabular}

*bold values indicate stationarity

Source: Computed by researcher using eviews9

Table 4. Unit Root Test for KAB (KPSS Test)

\begin{tabular}{|l|l|l|l|}
\hline Data & Asymptotic Critical Value & Level of Sig. & LM Statistic \\
\hline \multirow{3}{*}{ Level } & $\mathbf{0 . 2 1 6 0}$ & $1 \%$ & \\
\cline { 2 - 3 } & $\mathbf{0 . 1 4 6 0}$ & $5 \%$ & \multirow{2}{*}{0.1258} \\
\cline { 2 - 3 } & 0.1190 & $10 \%$ & \\
\hline
\end{tabular}

*bold values indicate stationarity

Source: Computed by researcher using eviews9

ADF test shows that the data of KAB series is stationary at all levels as the $t$ value is more than the absolute critical values thus rejecting the null hypothesis of "unit root series". Another thing to be noted is that both trend and intercept were selected while performing the $\mathrm{ADF}$ and the trend was found to be significant with Prob. of 0.0003 . Thus, it proves that appropriate model to be adopted is intercept and trend model. On the other hand, the same result is shown by KPSS test. According to its results, the series is stationary at all levels because the LM statistic is less than the appropriate critical value except at $10 \%$ level of significance. Even if first order differencing is used it will have no alteration in the decision of maximum order of integration ( $\mathrm{m}$ ) for both the series. Hence, the $\mathrm{m}$ for FDII and KAB is 1 , 
i.e. FDII is $\mathrm{I}(1)$ and $\mathrm{KA}$ is $\mathrm{I}(0)$.

With this maximum $m$ the VAR model $(1,1)$ is setup and the estimates are shown with $\mathrm{r}^{2}$ value of 0.9117 (Appendix 5). After setting up the VAR, tests for serial correlation and number of lags are performed. Serial correlation at three lags show that at two lag out of three there is no serial correlation in the model. Thus, this stand that there is no serial correlation in the VAR is accepted. The lag order selection criteria in Table 5 shows lag 1 minimizes the AIC, SC and HQ values and thus the VAR model $(1,1)$ and lags by information criteria is same.

Table 5. VAR Lag order selection criteria

\begin{tabular}{|c|c|c|c|c|c|c|}
\hline Las & $\log \mathrm{L}$ & LR & FPE & AIC & $\mathrm{SC}$ & HQ \\
\hline 0 & -493.6072 & NA & $1.27 \mathrm{e}+17$ & 45.05520 & 45.15438 & 45.07856 \\
\hline 1 & -466.1340 & $47.45366^{*}$ & $1.50 \mathrm{e}+16^{*}$ & $42.92127 *$ & $43.21883^{*}$ & $42.99137 *$ \\
\hline 2 & -464.0751 & 3.181892 & $1.82 \mathrm{e}+16$ & 43.09774 & 43.59367 & 43.21456 \\
\hline 3 & -458.4803 & 7.629350 & $1.62 \mathrm{e}+16$ & 42.95275 & 43.64705 & 43.11631 \\
\hline \multicolumn{7}{|c|}{ Endogenous variables: FDII KAB } \\
\hline \multicolumn{7}{|c|}{ Exogenous variables: $\mathrm{C}$} \\
\hline \multicolumn{7}{|c|}{ * indicates lag order selected by the criterion } \\
\hline \multicolumn{7}{|c|}{ LR: sequential modified LR test statistic (each test at $5 \%$ level) } \\
\hline \multicolumn{7}{|c|}{ FPE: Final prediction error } \\
\hline \multicolumn{7}{|c|}{ AIC: Akaike information criterion } \\
\hline \multicolumn{7}{|c|}{ SC: Schwarz information criterion } \\
\hline \multicolumn{7}{|c|}{ HQ: Hannan-Quinn information criterion } \\
\hline
\end{tabular}

Also the Inverse Root graph shows that model is stable as the values are less than unity (Appendix 3). Additionally, for having a cross check at the end of the analysis the cointegration test on the two series is conducted. The Johansen cointegration test shows that there is 1 cointegration at 5\% level of significance by Trace test as well as by maximum eigenvalue test. As cointegration has been found between FDII and KAB, it means that the final results must show Granger causality between FDII and KAB at least one way (Appendix 6). If VAR model does not approves at least one Granger causality, it would be presumed that VAR model has been misspecified.

Next step is to re-estimate VAR model with additional lag m (Appendix 5) followed by VAR Granger causality (Block Exogeneity Wald Test). The output of Granger causality is shown in Table 6 and Table 7 ,

Table 6. VAR Granger causality for FDII

\begin{tabular}{|l|l|l|l|}
\hline Excluded & Chi-sq. & df & Prob. \\
\hline KAB & 5.1655 & 1 & $\mathbf{0 . 0 2 3 0}$ \\
\hline
\end{tabular}

*bold values indicate rejection of $\mathrm{H}_{0}$

Source: Computed by researcher using eviews 9 
Table 7. VAR Granger causality for KAB

\begin{tabular}{|l|l|l|l|}
\hline Excluded & Chi-sq. & df & Prob. \\
\hline FDII & 5.2846 & 1 & $\mathbf{0 . 0 2 1 5}$ \\
\hline
\end{tabular}

*bold values indicate rejection of $\mathrm{H}_{0}$

Source: Computed by researcher using eviews 9

The $\mathrm{H}_{0}$ for Table 6 is that KAB does not Granger cause FDII and this null hypothesis is rejected as the Prob. is less than 5\% level of significance. Therefore, Capital Account Balance Granger cause FDI Inflows. Similarly, the null hypothesis of Table 7 is also rejected and alternative hypothesis is accepted which means that FDII Granger cause KAB. This proves that there is a bi-directional causality between FDII and KAB. The result does not stand contrary to cointegration and therefore must be accepted.

\section{Conclusion}

The discussion and analysis on the variable Foreign Direct Investment Inflows and the component of balance of payments Capital Account Balance (KAB) shows that there is an impact of Foreign Direct Investment Inflows on Capital Account Balance. However, the difference being, there is bi-directional causality between Capital Account Balance and Foreign Direct Investment Inflows. This means that Foreign Direct Investment Inflows impact the Capital Account Balance in India as well as the Capital Account Balance also impacts the Foreign Direct Investment Inflows. This proves the point that Foreign Direct Investment Inflows are very important macroeconomic variable for an emerging economy like India.

\section{References}

Abdulnasser, H., \& Manuchehr, I. (2000). Time-series evidence for Balassa's export-led growth hypothesis. Journal of International Trade and Economic Development, 9, 355-365. http://dx.doi.org/10.1080/09638190050086195

Ahmad, Fayyaz., Yang, Su-Chang., \& Draz, Muhammad. Umar. (2015). Causality between Foreign Portfolio Inflows and economic growth: Evidence from China and India. International Journal of Economics and Finance, 7(10), http://dx.doi.org/10.5539/ijef.v7n10p163

Baye, M. R., \& Jansen, D. W. (1995). Money, banking, and financial markets: An economics approach. Houghton Mifflin College Division.

Catao, Luis. A. V., \& Milesi-Ferretti, Gian. Maria. (2013). External Liabilities and Crises. IMF Working paper: WP/12/113. http://dx.doi.org/10.5089/9781484315910.001

Chakraborty, C., \& Basu, P. (2002). Foreign direct investment and growth in India: A cointegration approach. Applied Economics, 34, 1061-1073. http://dx.doi.org/10.1080/00036840110074079

Dickey, D. A., \& Fuller, W. A. (1981). Likelihood ratio statistics for Autoregressive Time 
Series with a unit root. Econometrica, 49(4), 1057-1072. http://dx.doi.org/10.2307/1912517

Dunning, J. H. (1981). International Production and the Multinational Enterprise, London: Allen and Unwin.

Dunning, J. H. (1993).The Globalization of Business. London: Routledge

Egbo, D. Macaulay. (1998). Foreign Direct Investment and the Performance of the Nigerion Economy, Proceedings of the 1st International Technology, Education and Environment Conference, African Society for Scientific Research.

Enderwick, Peter. (1985). MultinationalBusiness and Labour. New York, NY: St. Martin Press. (ISBN- 9780312552527).

Fry, M., Claessens, S., Burridge, P., \& Blanchet, M. (1995). Foreign Direct Investment, Other Capital Flows and Current Account Deficits: What Causes What? Working Paper no. 1527 (World Bank Policy Research).

Goldberg, S., \& Klein, W.(1999). International trade and factor mobility: an empirical investigation, NBER Working Paper 7196.

Hafbauer, G. L., \& Adler, F. (1968). Overseas manufacturing investments and the balance of payments, Tax Policy Research Study No. 1, US Treasury Department, Washington: DC.

Hossain, Muhammad. Amir. (2007). Impact of Foreign Direct Investment onBangladesh's Balance of Payments: Some Policy Implications.Retrieved from: http://www.researchgate.net/publication/254557421_Impact_of_Foreign_Direct_Investment_ on_Bangladesh's_Balance_of_Payments_Some_Policy_Implications

Ietto-Gillies, G. (1992). International Production Trends, Theories, Effects. Cambridge: Polity Press.

International Monetary Fund. (2003). Balance of Payments Statistics Yearbook. Washington: IMF.

Jhingam, M. L. (2008). Money, Banking, International Trade and Public Finance. Delhi, DL: Vrinda Publications (P) Ltd.

Kaur, Manpreet.,Yadav, Surendra. S., \&Gautam, Vinayshil. (2012). Foreign Direct Investment and Current Account Deficit- A causality analysis in context of India. Journal of International Business and Economy, 13(2), 85-106.

Kindleberger, Charles. P. (1985). International Capital movements, New York, NY: Cambridge University Press.

Kocenda, Evzen., \& Cerny, Alexander. (2014). Elements of Time Series econometrics: An Applied approach. Prague, Karolinum: Charles Univeristy

Kulkarni, Archana., \& Kamaiah, Bandi. (2015). Predicting balance of payments crises for some emerging economies. Theoretical and applied economics, 22, 1(602), pp. 15-34. 
Kwialkowski, D., Phillips, P., Schmidt, P., \& Shin, Y. (1992). Testing the null hypothesis of stationarity against the alternative of a unit root. Journal of Econometrics, 54, 159-178. http://dx.doi.org/10.1016/0304-4076(92)90104-Y

Lipsey, Richard. G, \& Chrystal, K. Alec. (2007). Economics. New York, NY: OUP Oxford.

Lutkepohl, Helmut. (2007). New Introduction to Multiple Time Series Analysis (ISBN: 3-540-26239-3). New Ypok, NY: Springer.

Nag, Biswajit., \& Mukherjee, Jaydeep. (2012). The sustainability of trade deficits in the presence of endogenous structural breaks: Evidence from the Indian economy. Journal of Asian Economics, 23, 519-526. http://dx.doi.org/10.1016/j.asieco.2012.05.003

Organisation for Economic Co-operation and Development. (2008). OECD Benchmark definition of Foreign Direct Investment (Fourth Edition). Retrieved from http://www.oecd.org/daf/inv/investmentstatisticsandanalysis/40193734.pdf

Pranadhani, Mayang., Bissoondeeal, Rakesh., \& Driffield, Nigel.(2007). FDI, Trade and growth, a causal Link. ISBN No: 978-1-85449-700-0.

Ranjan, Rajiv., \& Nachane, D. M. (2004). Analysis of the Capital Account in India's Balance of Payments. Economic and Political Weekly, 39(27), 3031-3044. Retrieved from http://www.jstor.org/stable/4415234

Reddaway, W. B. (1967). Effects of UK Direct Investment Overseas. An Interim report.University of Cambridge, Department of Applied Economics, Occasional Papers 12. Cambridge: Cambridge University Press

Reddaway, W. B. (1968). Effects of UK Direct Investment Overseas. Final Report.University of Cambridge, Department of Applied Economics, Occasional Papers n. 15.Cambridge: Cambridge University Press

Sahoo, D., \& Mathiyazhagan, M. K. (2002). Economic Growth in India: Does Foreign Direct Investment InflowMatter? Working Papers 115 (Institute for Social and Economic Change. Bangalore).

Sen, Pronab. (1995). Foreign Direct Investment: A Solution to BOP Problems? Economic and Political Weekly, Vol. 30, No. 30 (Jul. 29, 1995).Retrieved from: http://www.epw.in/special-articles/foreign-direct-investment-solution-bop-problems.html

Sims, Ch. (1980). Macroeconomics and Reality. Econometrica, 48, 1-49. http://dx.doi.org/10.2307/1912017

Thornton, J. (1996). Cointegration, causality and export-led growth in Mexico, 1895-1992. Economics Letters 50, 413-416. http://dx.doi.org/10.1016/0165-1765(95)00780-6

Toda, Hiro. Y., \& Tamamoto, Taku. (1995). Statistical inference in vector autoregressions with possibly integrated processes. Journal of Econometrics, 66, 225-250. http://dx.doi.org/10.1016/0304-4076(94)01616-8 
UNCTAD-DTCI. (1992). Transnational Corporations as Engines of Growth. World Investment Report 1995. Geneva: United Nations.

UNCTAD-DTCI. (1997). Transnational Corporations, Market Structure and CompetitionPolicy.World Investment Report 1997. Geneva: United Nations.

World Bank. (1993).Global Economic Prospectsat in the developing Countries. Washington, DC

World Bank. (1996). World Debt Tables: External Finance for Developing Countries. Vol. 1 (Analysis and Summary Tables). Washington, D. C.

\section{Appendix}

Appendix 1. Variable Description

\begin{tabular}{|l|l|}
\hline Variable & Description \\
\hline FDII & Foreign Direct Investment Inflows of India in US\$ millions \\
\hline KAB & Capital Account Balance of India's BOP in US\$ millions \\
\hline
\end{tabular}

Appendix 2. Matrix of FDII \& KAB of India (US\$ millions)

\begin{tabular}{|l|l|l|}
\hline Year & FDII & KAB \\
\hline $1991-92$ & 119.25 & 3915 \\
\hline $1992-93$ & 322 & 3876 \\
\hline $1993-94$ & 642.5 & 8894 \\
\hline $1994-95$ & 1268.25 & 8502 \\
\hline $1995-96$ & 2244.5 & 4089 \\
\hline $1996-97$ & 2798.5 & 12007 \\
\hline $1997-98$ & 3372.5 & 9844 \\
\hline $1998-99$ & 2516.75 & 8437 \\
\hline $1999-00$ & 2522.998 & 10444 \\
\hline $2000-01$ & 4029 & 8840 \\
\hline $2001-02$ & 6130 & 8551 \\
\hline $2002-03$ & 5035 & 10840 \\
\hline $2003-04$ & 4322 & 16736 \\
\hline $2004-05$ & 6051 & 28022 \\
\hline $2005-06$ & 8961 & 25470 \\
\hline $2006-07$ & 22826 & 45203 \\
\hline $2007-08$ & 34843 & 106585 \\
\hline $2008-09$ & 41873 & 7395 \\
\hline $2009-10$ & 37745 & 51634 \\
\hline $2010-11$ & 34847 & 63740 \\
\hline $2011-12$ & 46556 & 67755 \\
\hline $2012-13$ & 34298 & 89300 \\
\hline
\end{tabular}




\begin{tabular}{|l|l|l|}
\hline $2013-14$ & 36046 & 48787 \\
\hline $2014-15$ & 44877 & 89959 \\
\hline
\end{tabular}

Source: UNCTAD, DIPP, RBI; Transformed through eviews

Appendix 3. Additional Figures

Inverse Roots of AR Charac teristic Polynomial (FDII \& KAB

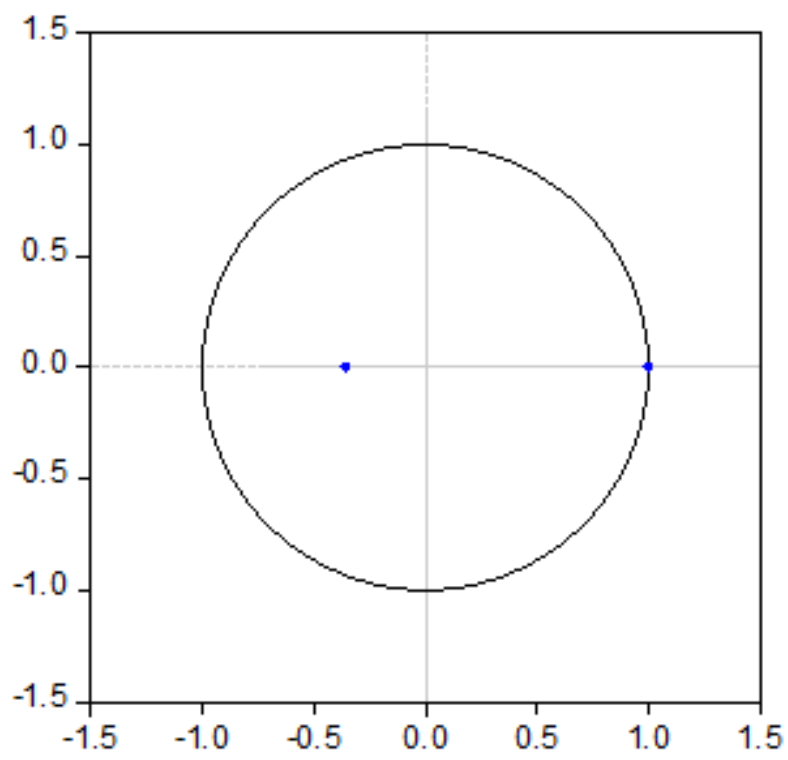

Appendix 4. Summary Statistics

\begin{tabular}{|l|l|l|}
\hline Descriptive & FDII & KAB \\
\hline Mean & 16010.26 & 30784.38 \\
\hline Median & 5543 & 11423.5 \\
\hline Maximum & 46556 & 106585 \\
\hline Minimum & 119.25 & 3876 \\
\hline Std. Dev. & 17303.47 & 31680.18 \\
\hline Skewness & 0.638389 & 1.099676 \\
\hline Kurtosis & 1.631331 & 2.888209 \\
\hline Jarque-Bera & 3.503414 & 4.849644 \\
\hline Probability & 0.173478 & 0.088494 \\
\hline Sum & 384246.2 & 738825 \\
\hline Sum Sq. Dev. & $6.89 \mathrm{E}+09$ & $2.31 \mathrm{E}+10$ \\
\hline Observations & 24 & 24 \\
\hline
\end{tabular}

Source: Computed by researcher using eviews9 
Appendix 5. VAR Models Output: FDII \& KAB

Default VAR (p lag)

Standard errors in ( ) \& t0statistics in [ ]

\begin{tabular}{|l|l|l|}
\hline & FDII & KA \\
\hline \multirow{3}{*}{ FDII (-1) } & 0.828832 & 1.739406 \\
\cline { 2 - 3 } & $(0.10920)$ & $(0.42168)$ \\
\cline { 2 - 3 } & {$[7.58993]$} & {$[4.12497]$} \\
\hline \multirow{4}{*}{ KAB (-1) } & 0.119649 & -0.180690 \\
\cline { 2 - 3 } & $(0.06112)$ & $(0.23599)$ \\
\cline { 2 - 3 } & {$[1.95775]$} & {$[-0.76565]$} \\
\hline \multirow{4}{*}{ } & 1013.457 & 11112.55 \\
\cline { 2 - 3 } & $(1534.46)$ & $(5925.25)$ \\
\cline { 2 - 3 } & {$[0.66047]$} & {$[1.87546]$} \\
\hline
\end{tabular}

Source: Computed by researcher using eviews 9

RE-estimated VAR (n lag)

Standard errors in ( ) \& [ ]

\begin{tabular}{|l|l|l|}
\hline & FDII & KA \\
\hline \multirow{3}{*}{ FDII (-1) } & 0.718977 & 2.422610 \\
\cline { 2 - 3 } & $(0.26281)$ & $(1.05385)$ \\
\cline { 2 - 3 } & {$[2.73576]$} & {$[2.29882]$} \\
\hline \multirow{3}{*}{ KAB (-1) } & 0.150727 & -0.192651 \\
\cline { 2 - 3 } & $(0.06632)$ & $(0.26593)$ \\
\cline { 2 - 3 } & {$[2.27278]$} & {$[-0.72443]$} \\
\hline \multirow{3}{*}{ C } & 438.9640 & 11880.99 \\
\cline { 2 - 3 } & $(1704.95)$ & $(6836.78)$ \\
\cline { 2 - 3 } & {$[0.25746]$} & {$[1.73780]$} \\
\hline \multirow{3}{*}{ FDII (-2) } & -0.093814 & -0.596999 \\
\cline { 2 - 3 } & $(0.22001)$ & $(0.88224)$ \\
\cline { 2 - 3 } & {$[-0.42640]$} & {$[-0.67669]$} \\
\hline \multirow{3}{*}{ KAB (-2) } & 0.099986 & -0.089447 \\
\cline { 2 - 3 } & $(0.07419)$ & $(0.29750)$ \\
\cline { 2 - 3 } & {$[1.34771]$} & {$[-0.30067]$} \\
\hline
\end{tabular}

Source: Computed by researcher using eviews 9 
Appendix 6. Cointegration Test Output: FDII \& KAB

\begin{tabular}{|l|l|l|l|l|}
\hline \multicolumn{4}{|l|}{ Unrestricted Cointegration Rank Test (Trace) } \\
\hline Hypothesized No. of CE(s) & Eigenvalue & Trace Statistic & 0.05 critical value & Prob. \\
\hline None & 0.610904 & 27.59061 & 25.87211 & 0.0303 \\
\hline At most 1 & 0.225598 & 5.880261 & 12.51798 & 0.4757 \\
\hline Result: Trace test indicates 1 cointegratingeqn(s) at the 0.05 level \\
\hline Unrestricted Cointegration Rank Test (Maximum Eigenvalue) \\
\hline Hypothesized No. of CE(s) & Eigenvalue & Max-Eigen Statistic & 0.05 critical value & Prob. \\
\hline None & 0.610904 & 21.71035 & 19.38704 & 0.0226 \\
\hline At most 1 & 0.225598 & 5.880261 & 12.51798 & 0.4757 \\
\hline Result: Max-Eigenvalue test indicates 1 cointegratingeqn(s) at the 0.05 level \\
\hline
\end{tabular}

Source: Computed by researcher using eviews 9

\section{Copyright Disclaimer}

Copyright for this article is retained by the author(s), with first publication rights granted to the journal.

This is an open-access article distributed under the terms and conditions of the Creative Commons Attribution license (http://creativecommons.org/licenses/by/3.0/). 